\title{
USULAN PERBAIKAN LINTASAN PRODUKSI DENGAN MENGGUNAKAN METODE THEORY OF CONSTRAINT DAN METODE MODDIE YOUNG
}

\author{
Mifthahul Ahyan ${ }^{1}$, Eddy $^{2}$, Uun Novalia Harahap ${ }^{3}$ \\ 1,2,3 Program Studi Teknik Industri, Fakultas Teknik dan Komputer, Universitas Harapan Medan \\ Email : mifthahulahyan@gmail.com
}

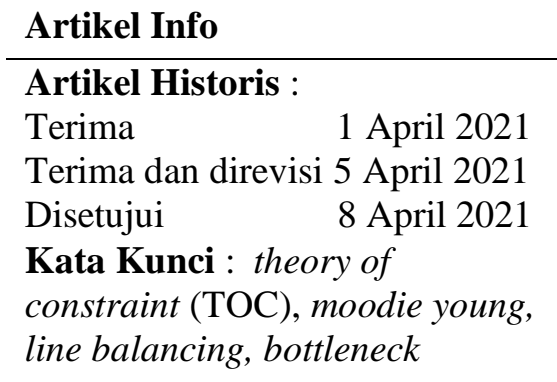

Keywords : theory of constraint (TOC), moodie young, line balancing, bottleneck

\begin{abstract}
Abstrak
PT. XYZ merupakan salah satu perusahaan manufaktur yang bergerak di bidang vulkanisir ban di Sumatera Utara. Pada kondisi aktual, terjadi antrean pada lantai produksi dikarenakan penumpukan barang yang diproses pada beberapa stasiun kerja atau sering disebut bottleneck. Hal ini dinilai mengakibatkan throughput pada perusahaan dalam proses yang tidak optimal. Oleh karena itu penulis merancang usulan perbaikan dengan menggunakan penjadwalan stasiun kerja berdasarkan stasiun kerja dengan upaya untuk mengeliminasi stasiun kerja bottleneck dan mendapatkan keseimbangan lintasan pada lantai produksi. Penjadwalan tersebut hanya dapat mengurangi jumlah stasiun kerja bottleneck sehingga dilakukan penyusunan stasiun kerja berdasarkan kriteria line balancing. Dalam penelitian ini, metode yang dipakai adalah Theory of Constraint (TOC) dan metode Moodie Young yang dapat menyelesaikan masalah yang ada sehingga waktu produksi lebih efisien. Perbaikan dilakukan adalah penjadwalan stasiun kerja dengan bottleneck yang menjadi kendala yaitu pada stasiun kerja skiving, cementing, repairing, envolving dan finishing, sehingga diperoleh 7 stasiun kerja dengan nilai smoothing index 709,43 dan efisiensi lintasan 75,44\%. Perbaikan dengan metode Moodie Young terdiri dari dua fase yaitu membuat pengelompokan stasiun kerja dan melakukan redistribusi elemen kerja ke setiap stasiun kerja hasil dari fase satu. Hasil penyeimbangan dengan menggunakan metode Moodie Young diperoleh 8 stasiun kerja dengan nilai smoothing index 917,40 dan efisiensi lintasan $74,70 \%$.
\end{abstract}

\footnotetext{
Abstract

PT. XYZ is a manufacturing company engaged in tire retreading in North Sumatra. In actual conditions, there is a queue on the production floor due to piling up of processed goods at several work stations or often called bottlenecks. This is considered to result in the company's throughput in the process that is not optimal. Therefore, the authors designed the improvement proposal by using work station scheduling based on work stations in an effort to eliminate bottleneck work stations and get a balance of trajectories on the production floor. This scheduling can only reduce the number of bottleneck work stations so that work stations are arranged based on line
}

Hal 59 dari 70 


\section{JURNAL ILMIAH TEKNIK MESIN, INDUSTRI, ELEKTRO DAN SIPIL}

Usulan perbaikan lintasan produksi dengan menggunakan metode theory of constraint dan metode moddie young

balancing criteria. In this study, the methods used are Theory of Constraint (TOC) and the Moodie Young method which can solve existing problems so that production time is more efficient. Improvements carried out were scheduling work stations with bottlenecks that became the constraints, namely skiving, cementing, repairing, envolving and finishing work stations, so that 7 work stations are obtained with a smoothing index value of 709.43 and a track efficiency of $75.44 \%$.The improvement using the Moodie Young method consists of two phases, namely creating a workstation grouping and redistributing the work elements to each work station resulting from phase one. The balancing results using the Moodie Young method obtained 8 work stations with a smoothing index value of 917.40 and line efficiency of $74.70 \%$.

\section{PENDAHULUAN}

Pada era globalisasi ini, perusahaan akan menghadapi persaingan yang semakin kompetitif. Perusahaan dituntut untuk mampu bersaing dalam memberikan produk yang terbaik agar memuaskan konsumen. Kondisi masyarakat saat ini yang semakin kritis dalam hal penilaian produk juga mempengaruhi perusahaan untuk melakukan berbagai upaya perbaikan proses yang terus menerus agar dapat mempertahankan dan meningkatkan hasil produksinya.

Lintasan produksi adalah penempatan areaarea kerja dimana operasi-operasi diatur secara berurutan dan material bergerak secara berkelanjutan melalui operasi yang terangkai seimbang [1].

Lintasan produksi mencakup paduan antara stasiun kerja (mesin dan peralatan) yang digunakan untuk menghasilkan produk. Biasanya, ini berisi banyak area kerja dan diambil alih oleh satu atau lebih operator sehingga berbagai alat dapat digunakan untuk menanganinya. Tujuan utama untuk mempersiapkan lintasan produksi adalah untuk membentuk dan menyeimbangkan beban kerja yang dialokasikan untuk setiap stasiun kerja [2].

Permasalahan pada lintasan produksi banyak terjadi pada proses perakitan suatu produk dibandingkan dengan proses pabrikasi.
Dalam pabrikasi biasanya part-part membutuhkan mesin berat dengan peralatan yang berbeda dibutuhkan secara proses seri, maka akan sulit untuk menyeimbangkan panjangnya waktu siklus mesin yang pada akhirnya akan menghasilkan rendahnya penggunaan kapasitas [3].

Theory of constaint (TOC) yang juga dikenal sebagai Constraint Management (CM) atau Syncrohonous Management adalah metodologi yang berfokus pada masalahmasalah penting pada sebuah sistem. Inti dari TOC adalah pengidentifikasian kendala-kendala sistem dan memutuskan bagaimana menyelesaikan kendala tersebut sehingga mencapai keadaan proses produksi yang seimbang. Penerapan theory of constraint dan line balancing dapat menyelesaikan permasalahan bottleneck dan meningkatkan efisiensi lintasan produksi sebanyak 9,18\% dengan mengurangi jumlah stasiun kerja dari 6 menjadi 5 stasiun kerja [4].

Penerapan theory of constraint dan line balancing dapat menyelesaikan permasalahan bottleneck dan meningkatkan efisiensi lintasan produksi sebanyak $9,18 \%$ dengan mengurangi jumlah stasiun kerja dari 6 menjadi 5 stasiun kerja. Hal ini membuktikan bahwa penerapan theory of constraint dapat menyelesaikan permasalahan bottleneck dan menyeimbangkan lintasan produksi [5]. 


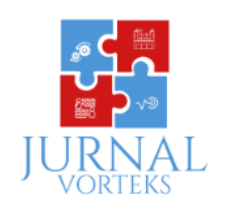

\section{JURNAL ILMIAH TEKNIK MESIN, INDUSTRI, ELEKTRO DAN SIPIL}

Usulan perbaikan lintasan produksi dengan menggunakan metode theory of constraint dan metode moddie young
Bottleneck adalah akumulasi bahan atau produk yang akan diproduksi ke tahap selanjutnya dalam jangka waktu tertentu. Bottleneck ini akan mengurangi kegunaan komponen produksi lainnya seperti mesin dan pekerja yang dapat menyebabkan stasiun kerja menjadi tidak optimal, efektif, dan efisien [6].

PT. XYZ merupakan perusahaan yang bergerak dalam bidang industri manufaktur vulkanisir ban dengan memproduksi dua jenis ban yaitu ban besar dan ban kecil. Ban besar dipasarkan kepada perusahaan alat angkut berat yaitu truk dan bus. Sedangkan ban kecil di pasarkan kepada perusahaan angkutan umum.

Aliran proses produksi dari suatu stasiun kerja ke stasiun kerja lainnya merupakan bagian dari waktu proses (waktu siklus) produk tersebut. Waktu siklus adalah waktu yang diperlukan untuk membuat satu unit produk pada suatu stasiun kerja [7].

Apabila terjadi hambatan dalam suatu stasiun kerja akan mengakibatkan tidak lancarnya aliran bahan ke stasiun kerja berikutnya, sehingga terjadi waktu menunggu (delay time), penumpukan bahan dan produk yang dihasilkan tidak sesuai dengan jam kerja yang telah direncanakan.

Tujuan dari penelitian ini adalah untuk memecahkan masalah ketidakseimbangan waktu proses pada setiap stasiun kerja yang mengakibatkan antrean produk sehingga terjadinya penumpukan pada stasiun kerja atau sering disebut dengan bottleneck dan mengeliminasi stasiun kerja bottleneck agar mendapatkan keseimbangan lintasan pada lantai produksi.

\section{METODE PENELITIAN}

Kerangka konseptual penelitian menunjukkan hubungan logis antara variabel-variabel yang telah didefinisi yang penting dan menjadi fondasi dalam melaksanakan penelitian. Kerangka konseptual penelitian ini dapat dilihat gambar 1 


\section{JURNAL ILMIAH TEKNIK MESIN, INDUSTRI, ELEKTRO DAN SIPIL}

Usulan perbaikan lintasan produksi dengan menggunakan metode theory of constraint dan metode moddie young

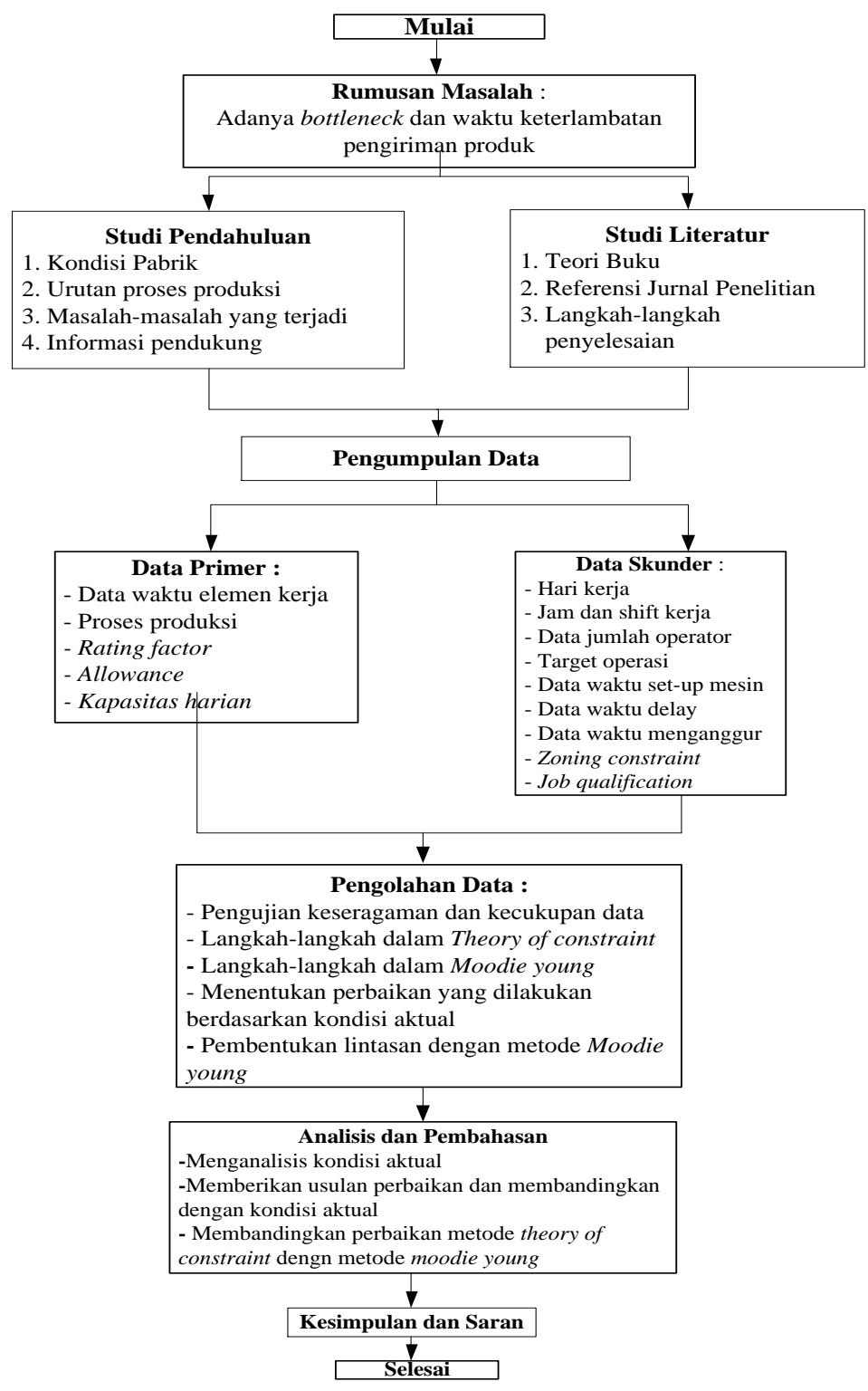

Gambar 1. Flowchart Metodologi Penelitian 


\section{JURNAL ILMIAH TEKNIK MESIN, INDUSTRI, ELEKTRO DAN SIPIL}

\section{Usulan perbaikan lintasan produksi dengan menggunakan metode}

theory of constraint dan metode moddie young

Jenis penelitian yang dilakukan di PT.XYZ tergolong penelitian deskriptif yang berbentuk job and analysis dengan tujuan untuk menyelidiki secara terperinci aktivitas dan pekerjaan seseorang atau sekelompok orang agar mendapatkan rekomendasi untuk berbagai keperluan, seperti misalnya keseimbangan beban kerja serta efisiensi dalam penggunaan waktu.

Adapun sumber data yang digunakan dalam penelitian ini adalah data primer dan data sekunder. Data Primer berupa data yang diperoleh secara langsung menggunakan instrumen berupa alat pengumpulan data. Data yang termasuk kategori ini adalah data urutan proses produksi, data waktu elemen kerja, data waktu perpindahan, rating factor, allowance, kapasitas harian. Sedangkan data Sekunder berupa data yang diperoleh dengan mengambil dari dokumen perusahaan dan wawancara. Metode pengolahan data pada penelitian ini menggunakan pengujian keseragaman dan kecukupan data, pengujian waktu elemen kerja, pengujian waktu perpindahan, menggunakan langkah-langkah theory of constraint, menentukan bagaimana mengetahui kendala yang ada dengan perhitungan waktu standar, perhitungan waktu yang dibutuhkan dan waktu yang tersedia, dan identifikasi stasiun kerja bottleneck, menentukan perbaikan yang dilakukan berdasarkan kondisi yang ada, melakukan penjadwalan pada stasiun kerja sebelum stasiun kerja bottleneck, stasiun kerja saat bottleneck dan stasiun kerja sesudah bottleneck, melakukan perhitungan efisiensi lintasan dan smotthing index dari kondisi aktual.

Analisis dilakukan dengan menguraikan hasil pengolahan data sehingga dapat ditemukan akar permasalahan yang selanjutnya dievaluasi. Pada penelitian ini dilakukan analisis kondisi aktual dari perusahaan, kemudian analisis penyelesaian masalah dilakukan dengan mengidentifikasi kendala (constraints) untuk mengetahui halhal yang mengakibatkan adanya bottleneck. Dimana bottleneck ini terjadi karena adanya perbedaan waktu proses pada setiap stasiun kerja sehingga terjadi penumpukan barang.

\section{HASIL DAN PEMBAHASAN}

\section{a. Pengujian Waktu Elemen Kerja}

Langkah awal pengujian keseragaman dan kecukupan data adalah perhitungan waktu ratarata elemen dari sepuluh pengamatan dalam 2 hari. Perhitungan waktu rata-rata elemen kerja dimulai dari elemen kerja 1 hingga elemen kerja 27.

\section{a. Uji Keseragaman Data}

Uji keseragaman data perlu dilakukan terlebih dahulu sebelum menggunakan data agar dapat diketahui apakah data sudah dalam keadaan seragam untuk menetapkan waktu standar. Untuk Menguji keseragaman data digunakan metode statistik dan tingkat keyakinan dan tingkat ketelitian yang diinginkan pengukur adalah tingkat keyakinan $95 \%$ dan tingkat ketelitian 5\% sebagai contoh dapat dilihat perhitungan pada stasiun kerja inspeksi awal.

a) Perhitungan standar deviasi adalah sebagai berikut:

$$
\begin{aligned}
& s=\sqrt{\frac{\sum_{i=1}^{n}\left(x_{i}-x\right)^{2}}{n-1}} \\
& s=\sqrt{\frac{(264-253,75)^{2}+\cdots+(245-253,75)^{2}}{20-1}} \\
& s=10,53
\end{aligned}
$$

b) Perhitungan batas kelas atas dan batas kelas bawah adalah sebagai berikut:

$$
\begin{aligned}
\mathrm{BKA}=x+2 s & =253,75+2(10,53) \\
& =274,81 \\
\mathrm{BKB}=x-2 s & =253,75-2(10,53) \\
& =232,69
\end{aligned}
$$

c) Pembuatan peta kontrol

Pembuatan peta kontrol dilakukan dengan memasukkan data waktu siklus yang dilengkapi dengan nilai BKA, BKB, dan nilai 


\section{JURNAL ILMIAH TEKNIK MESIN, INDUSTRI, ELEKTRO DAN SIPIL}

Usulan perbaikan lintasan produksi dengan menggunakan metode theory of constraint dan metode moddie young

rata-rata. Peta kontrol uji keseragaman waktu elemen kerja 1 dapat dilihat pada Gambar 2.

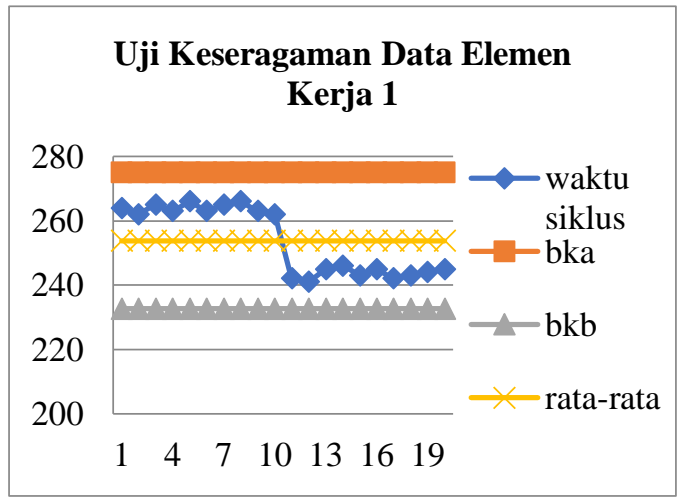

Gambar 2. Uji keseragaman Data Waktu Elemen Kerja

\section{b. Uji Kecukupan Data}

Berdasarkan hasil perhitungan diatas diperoleh $N>N^{\prime}(20>2,62)$ maka disimpulkan bahwa data waktu siklus untuk elemen kerja 1 yang diamati telah cukup. Hasil uji kecukupan data secara keseluruhan data telah dinyatakan cukup.

\section{c. Pengujian Waktu Perpindahan}

Perhitungan waktu perpindahan rata-rata didapat dari sepuluh pengamatan dalam dua hari. Sebagai contoh perhitungan waktu perpindahan rata-rata pada stasiun kerja inspeksi awal, adalah sebagai berikut:

$$
\begin{gathered}
x=\frac{\text { waktu perpindahan hari } I+\text { perpindahan hari } I I}{2} \\
x=\frac{11,40+13,20}{2}=12,30
\end{gathered}
$$

Setelah didapat hasil rata-rata perpindahan pada stasiun kerja maka, maka dilakukan uji keseragaman data dan uji kecukupan data untuk mendapatkan hasil yang segaram dan cukup.

\section{Uji Keseragaman Data}

Sebagai contoh perhitungan pada stasiun kerja inspeksi awal.

a. Perhitungan standar deviasi adalah sebagai berikut:

$$
\begin{gathered}
s=\sqrt{\frac{\sum_{i=1}^{n}\left(x_{i}-x\right)^{2}}{n-1}} \\
s=\sqrt{\frac{(11-12,30)^{2}+\ldots+(11-12,30)^{2}}{20-1}} \\
s=1,53
\end{gathered}
$$

b. Perhitungan batas kelas atas dan batas kelas bawah adalah sebagai berikut:

$\mathrm{BKA}=x+2 s=12,30+2(1,53)=15,35$

$\mathrm{BKB}=x-2 s=12,30-2(1,53)=9,25$

c. Pembuatan peta kontrol

Pembuatan peta kontrol dilakukan dengan memasukkan data waktu perpindahan yang dilengkapi dengan nilai BKA, BKB, dan nilai rata-rata. Peta kontrol uji keseragaman waktu perpindahan inspeksi awal dapat dilihat pada Gambar 3.

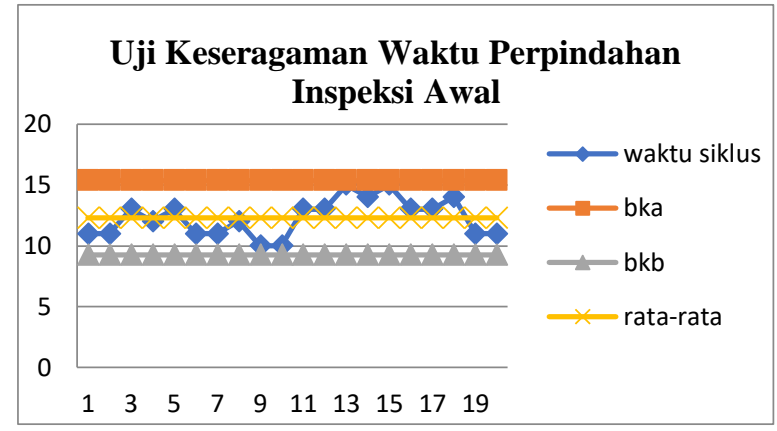

Gambar 3. Uji keseragaman Data Waktu Perpindahan Inspeksi Awal

2. Uji Kecukupan Data

Setelah data seragam maka selanjutnya dilakukan uji kecukupan data dengan rumus sebagai berikut:

$N^{\prime}=\left[\frac{\frac{k}{s} \sqrt{N \sum x_{i^{2}}-\left(\sum x_{i}\right)^{2}}}{\sum x_{i}}\right]^{2}$ 


\section{JURNAL ILMIAH TEKNIK MESIN, INDUSTRI, ELEKTRO DAN SIPIL}

Usulan perbaikan lintasan produksi dengan menggunakan metode theory of constraint dan metode moddie young

$N^{\prime}=\left[\frac{2 / 0,05 \sqrt{20(3214)-(246)^{2}}}{246}\right]^{2}$

$N^{\prime}=14,54$

Nilai $\mathrm{N}>N^{\prime}$ maka disimpulkan bahwa data yang telah diamati sudah cukup.

\section{Perhitungan Waktu Siklus Stasiun Kerja}

Waktu siklus stasiun kerja diperoleh dari penjumlahan waktu elemen kerja rata-rata pada setiap stasiun kerja sesuai dengan urutan proses produksi dan precedence diagram pada Gambar 5.4. Misalnya, waktu siklus stasiun kerja inspeksi awal diperoleh dari, EK 1 + EK $2=253,75+143,50=397,25$ detik.

\section{Langkah-langkah dalam Theory of Constraint (TOC)}

Dalam proses perbaikan pada penelitian ini, langkah-langkah dalam theory of constraint yang digunakan adalah sebagai berikut [8] :

\section{a. Identifikasi Kendala (constraint) Sistem}

Kendala-kendala yang diidentifikasi dapat berupa material, orang, mesin, tingkat permintaan atau berupa manajerial. Hasil identifikasi dari kendala tersebut adalah sebagai berikut:

1) Dari segi material, tidak terdapat kendala pada sistem. Hal ini dilihat dari material selalu tersedia pada saat proses produksi sehingga proses produksi tidak pernah terhenti akibat kurangnya atau ketidak tersediaan material.

2) Dari segi orang, tidak terdapat kendala pada sistem. Hal ini dilihat dari kemampuan operator pada saat melakukan pekerjaannya.

3) Dari segi mesin, tidak terdapat kendala pada sistem. Hal ini dilihat dari kemampuan mesin untuk memenuhi target produksi. Mesin yang digunakan bukan mesin yang tua atau rusak, sehingga jika waktu proses produksi berlangsung lama bukan dikarenakan adanya gangguan pada mesin.

4) Tingkat permintaan, tidak terdapat kendala ini pada sistem. Hal ini dilihat dari data permintaan vulkanisir ban besar dari Januari 2019 sampai Desember 2019 pada Gambar 3. Permintaan ban besar tidak mengalami penurunan yang drastis melainkan mengalami kenaikan.

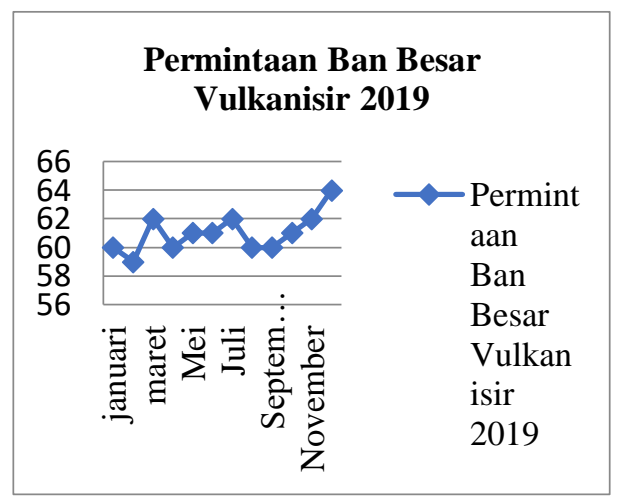

Gambar 4. Permintaan Ban Besar Vulkanisir

5) Dari segi manajerial, terdapat kendala pada sistem. Hal ini dapat dilihat dari tidak adanya Standard Operating Procedur (SOP) pada perusahaan ini. Sehingga pengaturan elemen kerja pada setiap stasiun kerja belum seimbang. Selain itu kelima hal diatas, constraint yang membatasi dan terdapat dalam sistem adalah adanya keterbatasan waktu proses pada setiap stasiun kerja sehingga mengakibatkan adanya waktu delay dan waktu menganggur (idle time).

6) Jika dianalisis berdasarkan precedence diagram dan flow process chart maka lintasan yang menjadi lintasan kritis adalah stasiun kerja skiving dan stasiun kerja finishing. Hal ini terjadi karena pada saat proses produksi, kemacetan aliran proses sering terjadi dan mengakibatkan adanya penumpukan ban.

\section{a) Tentukan Bagaimana Mengetahui Masalah dari Kendala yang Ada \\ Langkah-langkah untuk mengetahui kendala ini adalah dengan melakukan perhitungan waktu standar. Waktu standar diperoleh dari waktu normal yang telah di tambahi dengan kelonggaran-kelonggaran}




\section{JURNAL ILMIAH TEKNIK MESIN, INDUSTRI, ELEKTRO DAN SIPIL}

Usulan perbaikan lintasan produksi dengan menggunakan metode theory of constraint dan metode moddie young

(Allowance) yang dilakukan pekerja untuk memenuhi kebutuhan pribadi, menghilangkan fatigue (kelelahan), atau untuk hambatanhambatan yang tak terhindar. Sedangkan waktu normal diperoleh dari waktu siklus dan rating factor. Kapasitas terpasang merupakan kapasitas maksimum dari suatu fasilitas produksi. Kapasitas terpakai merupakan kapasitas yang digunakan untuk memproduksi dalam satu periode operasi.

Perhitungan waktu yang dibutuhkan Waktu yang dibutuhkan diperoleh dari total waktu standar untuk menghasilkan kapasitas produksi harian dalam satu hari setiap satu stasiun kerja. Waktu tersedia diperoleh dari total waktu keseluruhan dalam satu hari dikalikan dengan jumlah mesin yang dimiliki setiap stasiun kerja.

Bottleneck terjadi apabila waktu yang dibutuhkan lebih besar dari waktu yang tersedia dalam artian jika stasiun tersebut tidak bisa memproduksi sesuai dengan target produksi ban yang telah ditentukan sehingga terjadi penumpukan barang.

Terdapat lima stasiun kerja bottleneck yaitu stasiun kerja skiving, repairing, cementing, envolving, dan finishing. Dari hasil perhitungan ini terlihat jelas bahwa adanya kendala bottleneck dan adanya ketidakseimbangan waktu produksi setiap stasiun diakibatkan adanya waktu menganggur dan waktu delay.

Menentukan Perbaikan Berdasarkan Kondisi

Aktual

Dari langkah sebelumnya diperoleh bahwa terdapat kendala-kendala yaitu bottleneck dan ketidakseimbangan waktu produksi. Pada langkah ini, diberikan penjadwalan proses produksi terhadap stasiun bottleneck dan perhitungan keseimbangan lintasan berdasarkan kondisi aktual. Hal ini dilakukan untuk melihat bagaimana perbaikan yang dapat dilakukan untuk kendala-kendala yang ada.

Penjadwalan proses produksi berdasarkan stasiun kerja botlleneck terbesar. Langkahlangkah penjadwalan produksi adalah sebagai berikut:

Penjadwalan Backward
Penjadwalan mulai dari due date, bergerak berlawanan arah dengan arah pergerakan waktu. Penjadwalan pasti memenuhi due date tapi mungkin tidak fleksible yang dilakukan pada stasiun kerja sebelum stasiun kerja bottleneck [9]. Contoh perhitungan penjadwalan adalah sebagai berikut:

a. Menentukan waktu finish pada stasiun kerja Chambering.

$$
\begin{gathered}
=\sum \text { waktu stasiun }(I \text { s } / d \text { IX) }- \\
\text { - waktu perpindahan - waktu setup } \\
- \text { waktu delay } \\
- \text { waktu menganggur } \\
=20554,78-42,20-655,00-0,00 \\
-0,00 \\
=19857,58 \text { detik }
\end{gathered}
$$

a. Menentukan waktu start pada stasiun kerja Chambering.

= waktu finish stasiun chambering

- waktu standar stasiu chambering

- waktu proses dengan mesin

$$
\begin{aligned}
& =19857,58-465,62-9930,00 \\
& =9461,96 \text { detik }
\end{aligned}
$$

\section{Penjadwalan Bottleneck}

Penjadwalan yang dilakukan pada stasiun kerja bottleneck yaitu stasiun kerja finishing.

a. Menentukan waktu start stasiun kerja Finishing

$=19857,58+182,00+1980$

$+0,00+27,25$

$=22047,10$ detik

a. Menentukan waktu finish stasiun kerja Finishing

$=$ waktu start + waktu standar + waktu proses mesin

$=22047,10+848,83+0$

$=22895,93$ detik.

Tabel 1. Hasil Penjadwalan Backward, Bottleneck, Forward, dan Waktu Proses

$\begin{array}{cccc}\begin{array}{c}\text { Stasiun } \\ \text { Kerja }\end{array} & \begin{array}{c}\text { Start } \\ \text { (detik) }\end{array} & \begin{array}{c}\text { Finish } \\ \text { (detik) }\end{array} & \begin{array}{c}\text { Waktu } \\ \text { Proses }\end{array} \\ & & & \text { (detik) }\end{array}$

(detik) 
JURNAL ILMIAH TEKNIK MESIN, INDUSTRI, ELEKTRO DAN SIPIL

Usulan perbaikan lintasan produksi dengan menggunakan metode theory of constraint dan metode moddie young

\begin{tabular}{lccc}
\hline $\begin{array}{l}\text { Inspeksi } \\
\text { Awal }\end{array}$ & 0,00 & 459,19 & 459,19 \\
\hline Buffing & 1106,49 & 1681,94 & 575,45 \\
\hline Skiving & 2451,24 & 2866,09 & 414,85 \\
\hline Repairing & 3609,64 & 4199,24 & 589,60 \\
\hline Cementing & 4820,54 & 5314,10 & 493,56 \\
\hline Filling & 5822,10 & 6483,01 & 660,91 \\
rubber & & & \\
\hline Building & 6883,01 & 7717,02 & 834,01 \\
\hline Envolving & 7976,37 & 8571,56 & 595,19 \\
\hline
\end{tabular}

\begin{tabular}{lccc}
\hline Chamberi & 9461,96 & 19857,5 & 10395,6 \\
ng & \multicolumn{3}{c}{8} \\
\hline Finishing & 22047,1 & 22895,9 & 848,83 \\
& 0 & 3 & \\
\hline Inspeksi & 23254,3 & 23336,5 & 82,13 \\
akhir & 8 & 1 & \\
\hline
\end{tabular}

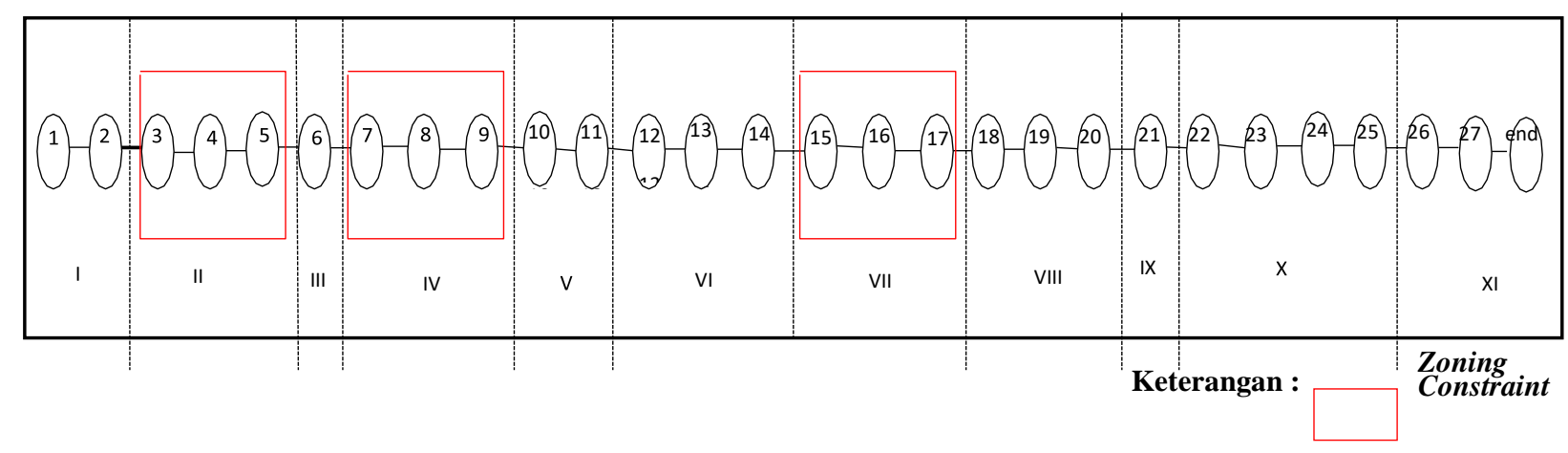

Gambar 5. Precedence Diagram Vulkanisir Ban Besar 


\section{JURNAL ILMIAH TEKNIK MESIN, INDUSTRI, ELEKTRO DAN SIPIL}

Usulan perbaikan lintasan produksi dengan menggunakan metode theory of constraint dan metode moddie young

Perhitungan Keseimbangan lintasan berdasarkan kondisi aktual.

Perhitungan ini dilakukan untuk melihat

Berdasarkan kondisi aktual maka dapat dihitung nilai efisiensi lintasan balance delay dan smoothing index.

Efisiensi lintasan adalah rasio antara waktu yang digunakan dengan waktu yang tersedia. Balance delay adalah ukuran dari ke tidak efisienan lintasan yang dihasilkan dari waktu menganggur. Smoothing index adalah suatu indeks yang mempunyai kelancaran relative dari penyeimbangan lintasan produksi tertentu [10].

Hasil yang diperoleh adalah sebagai berikut.

Smoothing Index,

$$
\begin{aligned}
& =\sqrt{\sum_{i=1}^{N}(W S K \max -W S K i)^{2}} \\
& =\sqrt{\begin{array}{c}
302^{2}+355^{2}+343^{2}+265^{2}+270^{2} \\
+143^{2}+195^{2}+323^{2}+339^{2}+0^{2}+629^{2}
\end{array}} \\
& =\sqrt{11513668} \\
& =1073,02 \\
& =\frac{\sum_{i-1}^{n} S i}{n \times C T} \times 100 \% \\
& =\frac{(398+345+\ldots+700+71)}{11 \times 700} \times 100 \% \\
& =\frac{4536}{7700} \times 100 \%=58,91 \% \\
& \text { Balance Delay } \\
& =\frac{n \times C T-\sum S i}{n \times C T} \times 100 \% \\
& =\frac{11 \times 700-(398+345+\cdots+700+71)}{11 \times 700} \times 100 \% \\
& =\frac{7700-(4536)}{7700} \times 100 \%
\end{aligned}
$$

Lintasan produksi pada kondisi awal dengan waktu siklus sebesar 700 detik dan terdapat 11 stasiun kerja. Diketahui nilai balance delay sebesar 41,09\%, efisiensi sebesar 58,91\% dan smoothing index sebesar 1073,02. Pada keadaan ini lintasan produksi dikatakan belum seimbang karena nilai efisiensi lintasan produksi belum mendekati nilai $100 \%$, sehingga perlu dilakukan perbaikan.

\section{Langkah-langkah dalam Moodie-Young}

\section{Pembentukan Lintasan Produksi dengan Metode Moodie Young}

Fase satu adalah membuat pengelompokan stasiun kerja. Pada fase satu dibuat precedence diagram untuk matriks $P$ dan matriks $F$ yang menggambarkan elemen kerja pendahulu dan elemen kerja yang mengikuti. Sebagai pemisalan, matriks $P$ menunjukkan hubungan elemen kerja pendahulu dan matriks $F$ menunjukkan hubungan elemen kerja yang mengikuti. Kemudian elemen kerja ditempatkan pada stasiun kerja yang berurutan dalam lintasan produksi dengan aturan, bila terdapat dua elemen kerja yang bisa dipilih maka elemen kerja yang mempunyai waktu lebih besar ditempatkan yang pertama. Fase dua dilakukan untuk mendistribusikan waktu menganggur (idle) secara merata untuk tiaptiap stasiun hasil dari fase satu [11].

Adapun langkah-langlah pembentukan lintasan produksi dengan menggunakan moodie young fase 1 dan moodie young fase 2 adalah sebagai berikut:

\section{Moodie Young Fase 1}

Membuat matriks $\mathrm{P}$ dan $\mathrm{F}$ yang menggambarkan elemen kerja pendahulu $(\mathrm{P})$ dan elemen kerja yang mengikuti (F) Berdasarkan Precedence diagram Gambar 4. maka dapat diketahui matriks $\mathrm{P}$ dan $\mathrm{F}$.

Melakukan pembebanan elemen kerja pada work center, sebagai acuan untuk digunakan adalah :

- waktu siklus sebesar 700 detik.

\section{- Precedence diagram}

- Zoning constraint yang telah ditetapkan. 


\section{JURNAL ILMIAH TEKNIK MESIN, INDUSTRI, ELEKTRO DAN SIPIL}

Usulan perbaikan lintasan produksi dengan menggunakan metode theory of constraint dan metode moddie young

1. Ditandai elemen kerja pada matriks P yang semua nilainya 0 . Ditempatkan elemen kerja tersebut pada suatu stasiun kerja (work center I). Jika ada 2 elemen yang mempunyai semua nilai 0 pada matriks $\mathrm{P}$, maka pilih waktu yang terbesar. Jika elemen kerja yang mungkin memiliki waktu yang sama, maka dipilih salah satu tanpa aturan. Hanya elemen kerja 1 yang mempunyai semua nilai 0 pada matriks $P$, maka elemen kerja 1 ditempatkan pada work center $\mathrm{I}$.

2. Ditandai elemen kerja yang ada pada matriks $F$ yang sesuai dengan elemen kerja yang telah ditempatkan pada stasiun kerja sebagai hasil langkah 1. Elemen kerja yang berhubungan dengan elemen kerja 1 adalah 2. Dan yang mungkin masuk adalah elemen kerja yang mempunyai semua nilai 0 pada matriks $P$ (setelah elemen kerja yang terpakai bernilai 0 ). Dilakukan langkah kedua tersebut berulang-ulang untuk mengisi work center hingga mencukupi acuan Waktu Siklus work center $=700$ detik.

\section{bMoodie Young Fase 2}

1. Identifikasi waktu stasiun kerja terbesar dan waktu stasiun kerja terkecil.

2. Tentukan Goal, dengan rumus :

goal $=\frac{\text { Wsiklus } \max -W \text { siklus } \min }{2}$

3. Identifikasi sebuah elemen kerja yang terdapat dalam stasiun kerja dengan waktu paling maksimum, yang mempunyai waktu yang lebih kecil daripada GOAL, yang elemen kerja tersebut bila dipindah ke stasiun kerja yang paling minimum tidak melanggar precedence diagram.

4. Pindahkan elemen kerja tersebut.

5. Lakukan evaluasi kembali hingga tidak ada lagi elemen kerja yang dapat dipindahkan.

W stasiun terbesar adalah WC Stasiun

Finishing $=700$ detik.

$\mathrm{W}$ stasiun terkecil adalah $\mathrm{WC}$ Stasiun $=71$ detik.
Maka dapat ditentukan GOAL,

goal $=\frac{700-71}{2}=314,5$ detik

Berdasarkan nilai GOAL diatas adalah sebesar 314,5 detik. Apabila terdapat elemen kerja yang dapat dipindahkan, maka elemen kerja 25 (301 detik) pada stasiun kerja Finishing dapat dipindahkan ke stasiun kerja Inspeksi akhir yang memiliki waktu siklus paling minimum. Hasil penyimbangan lintasan yang didapat dengan metode Moodie Young diperoleh 8 stasiun kerja dengan 13 operator.

\section{Perhitungan Efisiensi Lintasan, Balance} delay, dan Smoothing Index

Perhitungan keseimbangan lintasan produksi metode Moodie Young adalah:

\section{Balance Delay}

$$
\begin{aligned}
& =\frac{n \times C T-\sum S i}{n \times C T} \times 100 \% \\
& =\frac{6072-(4536)}{6072} \times 100 \% \\
& =25,30 \%
\end{aligned}
$$

\section{Efisiensi Lintasan}

$=\frac{\sum_{i-1}^{n} S i}{n \times C T} \times 100 \%$

$=\frac{3207}{8 \times 759} \times 100 \%$

$=74,70 \%$

Smoothing Index

$$
\begin{gathered}
=\sqrt{\sum_{i=1}^{N}(W S K \max -W S K i)^{2}} \\
=\sqrt{\begin{array}{c}
\left.16^{2}+402^{2}+\cdots+3^{2}\right) \\
\left.+0^{2}\right)+260^{2}
\end{array}}
\end{gathered}
$$

$=719,40$ 


\section{JURNAL ILMIAH TEKNIK MESIN, INDUSTRI, ELEKTRO DAN SIPIL}

Usulan perbaikan lintasan produksi dengan menggunakan metode theory of constraint dan metode moddie young

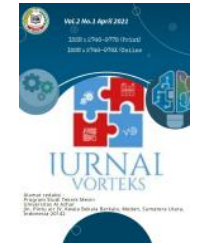

\section{KESIMPULAN}

Berdasarkan penelitian yang dilakukan di PT. XYZ diperoleh kesimpulan sebagai berikut:

1. Berdasarkan langkah-langkah metode Theory Of Constraint pada penelitian ini didapat stasiun kerja bottleneck yang menjadi kendala yaitu pada stasiun kerja skiving, cementing, repairing, envolving dan finishing.

2. Pada langkah penjadwalan jam kerja sebelum, saat, dan sesudah bottleneck diperoleh bahwa total waktu proses dari 24033,44 detik menjadi 15929,34 detik, tetapi masih terdapat stasiun kerja bottleneck yaitu stasiun kerja finishing. Berdasarkan line balancing, dengan menggunakan metode theory of constraint dibentuk satu alternatif lintasan yang terdiri 7 stasiun kerja dan 27 elemen kerja, dengan 14 operator. Adapun nilai efisiensi lintasan sebesar $74,44 \%$ dan smoothing index 709,43 .

3. Hasil penyeimbangan lintasan dengan metode Moodie Young diperoleh 8 stasiun kerja dengan 13 operator. Adapun nilai efisiensi lintasan $74,70 \%$ dan smoothing Index 719,40.

4. Keseimbangan lintasan produksi yang dipilih sebagai usulan perbaikan adalah metode Theory of Counstraint karena memiliki smoothing index yang lebih kecil dan efisiensi lintasan yang lebih besar.

\section{DAFTAR PUSTAKA}

[1] T. Baroto, "Perencanaan dan pengendalian produksi," Jakarta Ghalia Indonesia., 2002.

[2] R. Ginting, "Sistem produksi," Yogyakarta: Graha Ilmu, 2007.

[3] A. H. Nasution, "Perencanaan \& pengendalian produksi," 2003.

[4] M. V Shamuvel, Pandit, and G. R. Naik, "Application Of Theory Of Constraints On Scheduling Of Drum-Buffer-Rope System," IOSR J. Mech. Civ. Eng.
(IOSR-JMCE, pp. 15-20, 2013, [Online]. Available: wWw.iosrjournals.org.

[5] P. Ongkunaruk and W. Wongsatit, "An ECRS-based line balancing concept: a case study of a frozen chicken producer," Bus. Process Manag. J., vol. 20, no. 5, pp. 678-692, Aug. 2014, doi: 10.1108/BPMJ-05-2013-0063.

[6] J. E. Beer, Analysis and Management of Bottlenecks in Supply Networks. 2015.

[7] H. Purnomo, "Pengantar Teknik Industri, Edisi ke-2," Yogyakarta: Graha Ilmu, 2004.

[8] E. M. Goldratt and J. Cox, "The Goal: a process of on-going improvement," North River, Press. Inc, 1984.

[9] E. Patricia and H. Suryono, "Analisis Penjadwalan Kegiatan Produksi Pada Pt - Muliaglass Float Division Dengan Metode Forward Dan Backward," vol. 43, no. 1, pp. 71-79.

[10] T. Baroto, "Simulasi Perbandingan Algoritma Region Approach, Positional Weight, Dan Moodie-Young Dalam Efisiensi dan Keseimbangan Lini Produksi," J. Gamma, vol. 2, no. 1, 2006.

[11] D. Y. Handayani, B. Prihandono, and M. Kiftiah, "Analisis Metode Moodie Young Dalam Menentukan KeseimbanganLintasan Produksi Intisari," vol. 5, no. 03, pp. 229-238, 2016. 